\title{
Physicochemical Characteristics of Fresh-cut Tropical Fruit during Storage
}

\author{
Luh Suriati ${ }^{\mathrm{a}}$, I Made Supartha Utama ${ }^{\mathrm{b}}$, Bambang Admadi Harjosuwono ${ }^{\mathrm{b}}$, Ida Bagus Wayan Gunam ${ }^{\mathrm{b}}$ \\ ${ }^{a}$ Food Science and Technology Department Warmadewa University, Denpasar, Indonesia \\ Email: suryatiluh1@gmail.com \\ ${ }^{b}$ Department of Agricultural Engineering Udayana University, Denpasar, Indonesia
}

\begin{abstract}
Fresh-cut tropical fruit is increasingly popular currently, stimulated by public awareness of health and practical lifestylefresh-cut fruit presenting consumers' convenience, safety, and quality. Tropical fruit contains functional components that are quite varied and good for health. Mangosteen, Mango, and Rambutan are three exotic tropical fruits that have high economic value and are liked by foreign people. They have a nonedible relatively high and potentially processed into fresh-cut fruit-the process of stripping cutting and slicer, causing wounds that spur damage. During storage, fresh-cut fruits undergo physical-chemical changes-increased respiration rate, ethylene production, oxidation, and browning processes that can shorten shelf life. The damage will be faster if stored at an improper temperature. Fresh-cut fruit is preferably stored at cold temperatures, to extend the shelf life. The research aims to determine the physicochemical characteristics of fresh-cut tropical fruits during cold storage. The research uses a pattern of random group three replicate. The first factor is fruit type (Mango, Mangosteen, Rambutan); the second factor is storage time in cold temperatures $\left(0,5,10\right.$ days). The variables observed in the study included physical characteristics color $\left(L^{*} a^{*} b^{*}\right)$, weight, and texture. Observations of chemical characteristics include moisture content, $\mathrm{pH}$, total acids, vitamin $\mathrm{C}$ levels, and total dissolved solids. Freshcut tropical fruit has different physicochemical characteristics and experiences deterioration during cold temperatures. The characteristics of tropical fruit have changed significantly on day 5. Mango shows more significant changes than others, seen from variable moisture content, vitamin $\mathrm{C}$, color, and texture. Meanwhile, based on the physicochemical analysis, rigidity of fresh-cut Mango higher than Mangosteen and Rambutan.
\end{abstract}

Keywords — tropical fruit; physicochemical characteristics; fresh-cut; storage; shelf-life.

\section{INTRODUCTION}

The consumption of fruits in the world today has an increase that is stimulated by increased consumer awareness of health, storage technology, transportation, and marketing systems. Increasing consumption of fruit, mainly tropical fruit into a global strategy and priorities, leads to improve public health. Tropical fruit contains bioactive components such as phenolic compounds, carotenoids, organic acids, vitamins, and fibers that are very beneficial for health. Besides, a delicious tropical fruit also serves as a functional food, facilitates digestion, overcome obesity, increases immunity, as an antioxidant, anticancer, and antimicrobial [1]. The type of tropical fruit is very diverse in terms of shape, size, texture, a specific flavor [2]. Mangosteen, Mango, and Rambutan are three exotic tropical fruits that have high economic value and are liked by foreign people. The market prospects, both locally and exports, are potential and continue to improve. Fruits are a commodity that is perishable, easy to rot, and shrinking weight. The physiology damage of nonedible parts such as the skin often determines the preference of consumers, although the edible part of the fruit is still worth the consumption. The number of nonedible parts is relatively high compared to the edible, Mangosteen $63-75 \%$, Mango $22-29 \%$, Rambutan $52-57 \%$ is a high household garbage contributor. This increases sales trend parts of edible fruit (what you see, what you eat) through a minimal process known as fresh-cut fruit [3], [4].

The minimal process is a preparation of products such as stripping, cutting, slicing, washing, and packaging [5]. People nowadays prefer fresh-cut fruit products, driven by the need consumption of the quality products (fresh, healthy, comfortable, safe, nutritious) and lack of preparation time [6]. Some advantages of fresh-cut fruit are presenting consumers of options in one package, get the amount of fresh needed, facilitate the quality of the products purchased, reduce product volume and transportation cost [7].

The weakness of fresh-cut fruit is very easily damaged, and the shelf life is shorter than the whole fruit [8]. The minimal process resulted in tissue decay, so the fruit 
underwent physiological, pathological, and physical changes. Damages include increased tissue respiration, ethylene production, unexpected metabolites, degradation of sensory components, decreased fruit integrity, and microbial growth [9].

The decrease in quality and the short shelf life of freshcut fruit can lower the interest to consume it. Alternative methods during handling, distribution, and sales are essential to be considered so that when the fruit until the consumer's hands remain in fresh quality. Some ways can be done by observing the quality of raw materials, the application of calcium on the surface of the fruit, storage of cold temperatures, and the use of edible coating [4], [10], [19], [20]. Information about the characteristics of fresh-cut tropical fruit does not exist. Therefore, it needs research. The initial characterization of fresh-cut fruit is essential to precisely determine the next treatment to maintain quality and extend the shelf life. The study aims to determine the physicochemical characteristics of tropical fruits (Mango, Mangosteen, and Rambutan) during storage at cold temperatures.

\section{MATERIALS AND METHOD}

\section{A. Physicochemical analysis:}

Analysis of the physicochemical characteristics of tropical fruits using mangoes teen, Mango and Rambutan was processed minimally, by peeling and eliminating the peel and seed. Tropical fruits obtained from Buleleng Regency Bali Indonesia. Mango and Mangosteen was a tropical fruit that has a type of climacteric, while Rambutan was nonclimacteric fruit. Mangosteen was observed in the form of a merged segment while the Mango was cut into a cubeshaped 4x4x2 cm (without seed). Rambutan fruit was prepared without peel, but the seed was left. These fruits were packed in plastic boxes stored at cold temperatures $\left(7 \pm 1^{\circ} \mathrm{C}\right)$, as in Fig. 1 . The tools of research were digital scale analysis, refractometer, spectral colorimeter CS-280, chiller, digital $\mathrm{pH}$ meter, texture analyzer (speed 10 distance 20 for Mango, and speed 10 distance 8 for Rambutan) and instrument of titration.

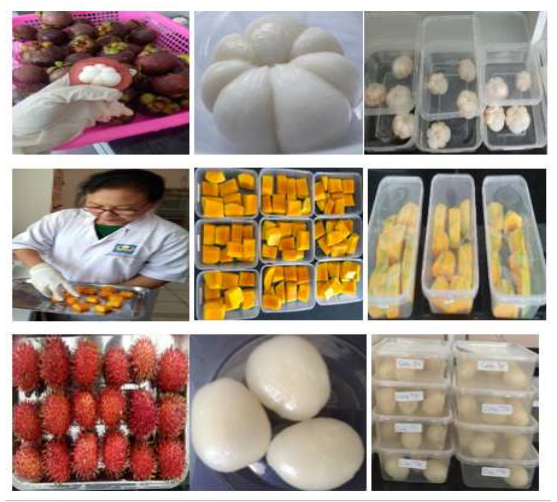

Fig. 1 Packing process fresh cut tropical fruits

\section{B. Statistical Analysis}

The design used a randomized draft of a factorial group with two replicates. The type of fruit was the first factor (Mango, Mangosteen, Rambutan), second factor time of storage $(0,5,10$ days). The variables observed included color, weight, texture, moisture content, $\mathrm{pH}$, total acids, vitamin C levels, total dissolved solids [11]. Data obtained is tested with ANOVA.

\section{RESULTS AND DISCUSSION}

The minimum process of different fruits contributes differently to the quality of fresh-cut produced. Fresh-cut fruit is comfortable, healthy, safe, quality, and relative have the desired shelf life. The quality and the shelf life of freshcut fruit depend on moisture content, degree of acidity $(\mathrm{pH})$, total acid, total dissolved solids, vitamin C, weights, colors, and textures. The results of the observation of tropical fruit, Mango, Mangosteen, and Rambutan can be seen in Table 1.

TABLE I

Moisture Content, PH, Total ACID, Total Dissolved Solids, Vitamin C, Weight, Colors AND TeXture of Fresh-Cut Tropical FRUIT

\begin{tabular}{|c|c|c|c|c|}
\hline $\begin{array}{l}\text { Fresh-cut } \\
\text { Fruit }\end{array}$ & Characteristics & Day-0 & $\begin{array}{c}\text { Day- } \\
5 \\
\end{array}$ & $\begin{array}{c}\text { Day- } \\
10 \\
\end{array}$ \\
\hline \multirow{11}{*}{ Mango } & Moisture \% & 80.91 & 82.36 & 77.37 \\
\hline & $\mathrm{pH}$ & 4.58 & 4.38 & 4.39 \\
\hline & Total acid (\%) & 0.35 & 0.30 & 0.26 \\
\hline & TDS $(\%)$ & 22.90 & 23.20 & 24.00 \\
\hline & Vitamin C (mg/100g) & 73.20 & 81.25 & 58.58 \\
\hline & Weight shrinkage $(\%)$ & 0.00 & 1.69 & 2.88 \\
\hline & Color: & & & \\
\hline & $\mathrm{L}^{*}$ & 51.99 & 42.38 & 39.12 \\
\hline & $\mathrm{a}^{*}$ & 11.32 & 10.37 & 6.19 \\
\hline & $\mathrm{b}^{*}$ & 89.51 & 67.30 & 34.71 \\
\hline & Texture $(\mathrm{N})$ & 3.39 & 2.11 & 1.90 \\
\hline \multirow{11}{*}{$\begin{array}{l}\text { Mangoes } \\
\text { teen }\end{array}$} & Moisture \% & 80.11 & 82.35 & 82.19 \\
\hline & $\mathrm{pH}$ & 3.13 & 3.02 & 2.98 \\
\hline & Total acid (\%) & 0.60 & 0.82 & 0.84 \\
\hline & TDS (\%) & 21.00 & 21.10 & 22.00 \\
\hline & Vitamin C (mg/100g) & 8.76 & 10.29 & 5.14 \\
\hline & Weight shrinkage $(\%)$ & 0.00 & 5.59 & 9.31 \\
\hline & Color: & & & \\
\hline & $\mathrm{L}^{*}$ & 56.89 & 44.58 & 28.32 \\
\hline & $a^{*}$ & -7.86 & -1.04 & 5.67 \\
\hline & $\mathrm{b}^{*}$ & 14.88 & 13.94 & 19.47 \\
\hline & Texture $(\mathrm{N})$ & 3.15 & 3,17 & 1,44 \\
\hline \multirow{11}{*}{ Rambutan } & Moisture \% & 78.81 & 80.36 & 79.51 \\
\hline & $\mathrm{pH}$ & 4.20 & 4.00 & 3.17 \\
\hline & Total acid (\%) & 0.48 & 0.74 & 0.76 \\
\hline & TDS (\%) & 19.40 & 23.00 & 24.50 \\
\hline & Vitamin C (mg/100g) & 58.37 & 43.19 & 33.28 \\
\hline & Weight shrinkage $(\%)$ & 0.00 & 4.15 & 6.92 \\
\hline & Color: & & & \\
\hline & $\mathrm{L}^{*}$ & 44.49 & 42.49 & 41.15 \\
\hline & $\mathrm{a}^{*}$ & 1.79 & -1.08 & -6.6 \\
\hline & $\mathrm{b}^{*}$ & 5.33 & 5.67 & 5.89 \\
\hline & Texture $(\mathrm{N})$ & 7.11 & 6.58 & 2.61 \\
\hline
\end{tabular}

\section{A. Moisture Content}

Moisture content determines the quality of fruits. The average moisture content of tropical fruits increases until day 5 then decreases again, as shown in Table 1 and Fig. 2. Processing with stripping and cutting causes tissue reduction and inducing respiration rate and spur velocity of moisture loss compared to intact tissue [12].

Respiration is the process by which organic ingredients (carbohydrates, proteins, and fats) break down into simpler end products and produce energy for its cell function. Once the fruit is separated from the tree, the respiration process continues to produce energy, or the tissues will die, which 
causes the cell aging process. The moisture content of the Mango ranges from 77.37-82.36\%, Mangosteen 80.11$82.35 \%$, and Rambutan 78.81-80.36\%. The highest moisture content during storage is found in Mangosteen. Moisture content of Mangosteen $82.6 \pm 0.2 \%$ [13]. The shelf life and quality of fresh-cut is considerably reduced by a series of decay processes triggered by physical damage, including moisture loss [9].

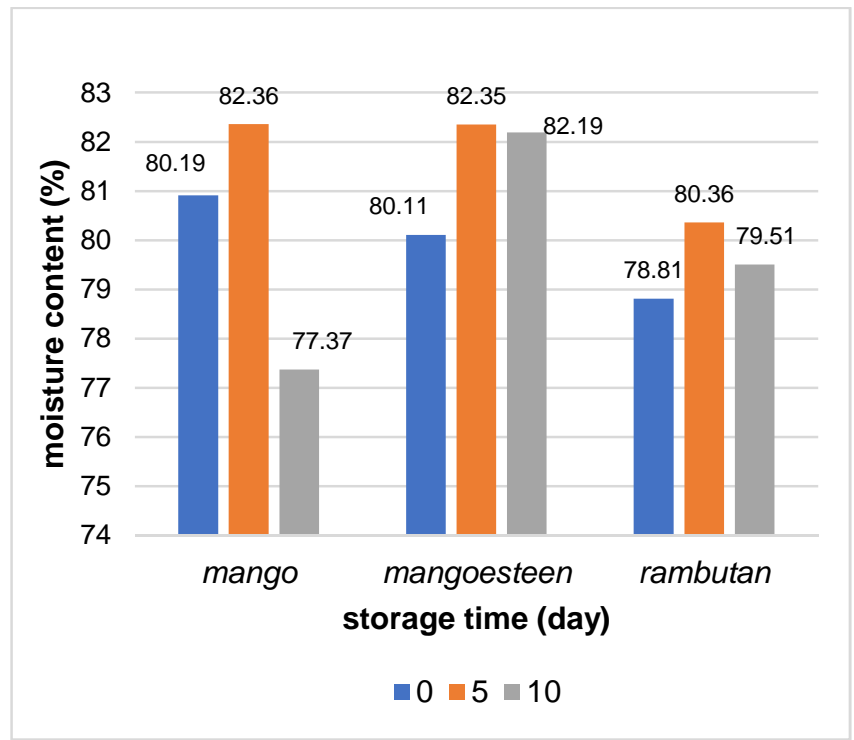

Fig. 2 Moisture content (\%) of fresh-cut tropical fruit during storage.

\section{B. Degree of Acidity $(\mathrm{pH})$}

Degree of acidity $(\mathrm{pH})$ often an indication of changes in the quality of fruits. Fruits mostly have low degree of acidity. The observation shows that the Mango has a $\mathrm{pH}$ range of 4.38-4.58, Mangosteen 2.98-3.13, Rambutan 3.174.2 (Table 1, Fig. 3).

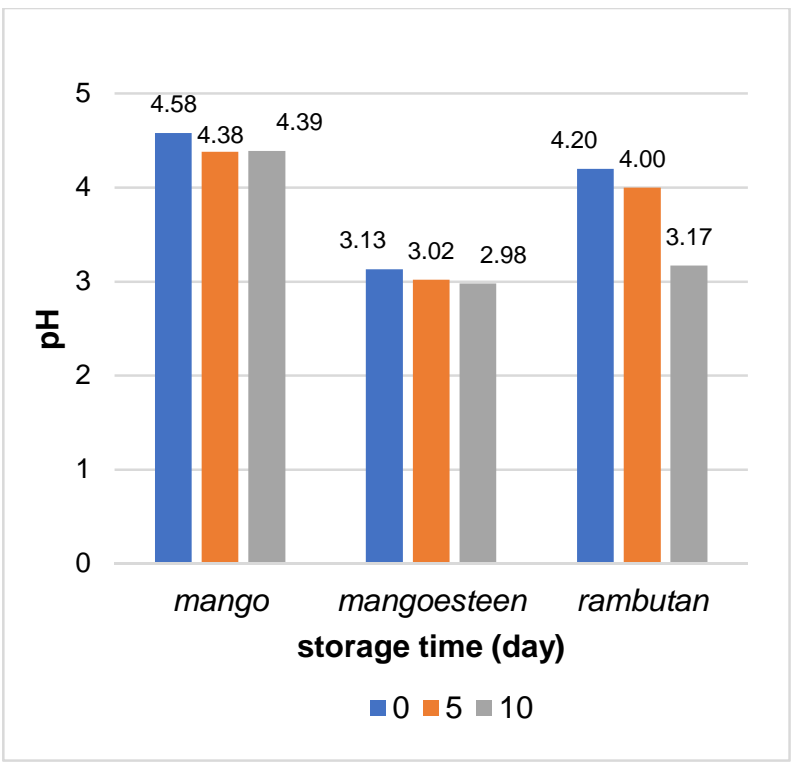

Fig. 3 Degree of acidity $(\mathrm{pH})$ of fresh-cut tropical fruit during storage.

All fruits show a decrease in $\mathrm{pH}$ during ten days of storage. Carbohydrates in fruits undergo conversion during storage and produce organic acids that contribute to decreased $\mathrm{pH}$. The change of carbohydrate or starch conversion into sugars, organic acids, fats, phenol, and folate compounds also occurs [18]. Rambutan fruit has a sharp decline. The results [12] specified, $\mathrm{pH}$ of rambutan fruit decreases significantly during storage. Mangosteen has the lowest $\mathrm{pH}$ among the three types of fruit. This is in line with the opinion [14], Mangosteen has a high degree of acidity.

\section{Total Acid}

Total acid is the number of organic acids in the fruit. The total acid of tropical fruits tends to increase during storage except for the mango fruit. The average value of total acid Mango fruit ranges between 0.26-0.35\%, Mangosteen 0.60$0.84 \%$, and Rambutan $0.48-0.76 \%$ (Table 1, Fig. 4). During storage, there is a decrease in total acid in Mango and Mangosteen. Mango and Mangosteen are climacteric fruit that is still experiencing maturation during storage.

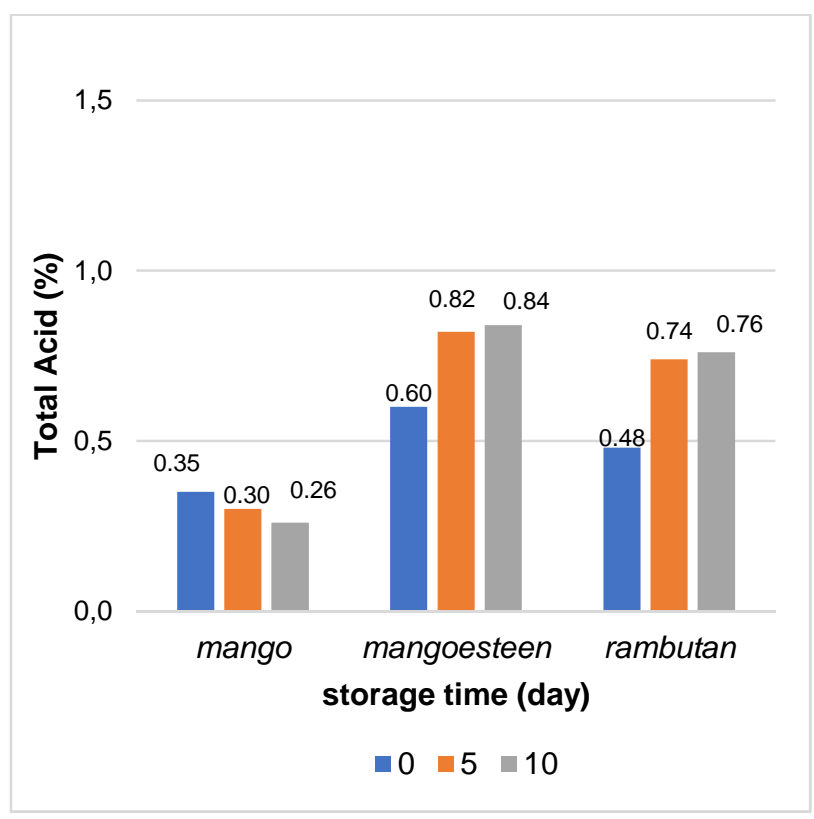

Fig. 4 Total acid (\%) of fresh-cut tropical fruit during storage.

Usually, after harvesting, the maturation process results in increased respiration, the production of ethylene, the change of carbohydrate or the conversion of starch into sugar, organic acids, fats, phenol, and folate compounds [9]. The highest total acid was obtained from Mangosteen fruit. Mangosteen contains a total of phenol $6.4 \pm 0.5$ (g/kg D. m), free phenolic acid $9.7 \pm 1.3 \%$, phenolic acid ester $76.5 \pm$ $5.0 \%$ and glycosides $13.8 \pm 3.3 \%$ [13].

\section{Total Dissolved Solids}

The total sugar of fruit increases due to the hydrolysis of starch content to simple sugars. If the sugar content is more dominant than its acid content causes the flavor that arises is sweet. The total dissolved solids contribute to increased sugar content in the fruit during maturation [15]. Conversion of carbohydrates or starch into sugars, organic acids, fats, phenol, and folate compounds contribute to total dissolved solids during storage [18].

The observation shows the total dissolved solids in the Mango fruit 22.9-24.00 Brix and Mangosteen 21.00-22.00 Brix remained relatively fixed during the 10-day storage (Table 1, Fig. 5). The total dissolved solids in the Rambutan 
$19.40-24.50$ Brix is also insignificant. The total dissolved solids in Rambutan during storage did not undergo significant changes [12].

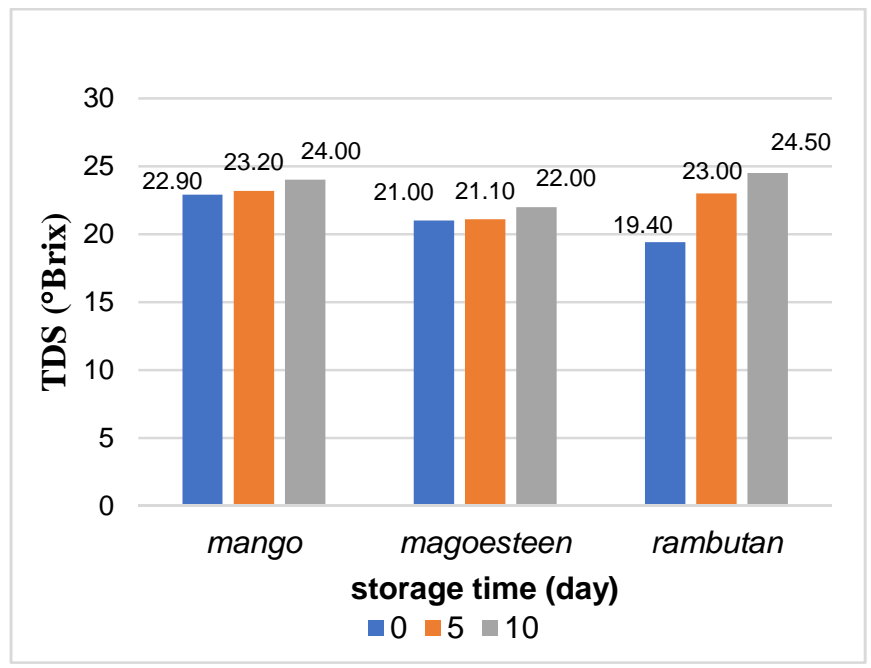

Fig. 5 Total dissolved solid (\%) of fresh-cut tropical fruit during storage.

\section{E. Vitamin $C$}

Vitamin $\mathrm{C}$ is a component of nutrients that are easily oxidized and degraded. The observation shows a tendency to decrease vitamin C by day 10 . Levels of vitamin C Mango $58.58-73.20 \mathrm{mg} / 100 \mathrm{~g}$, Mangoesteen $5.14-10.29 \mathrm{mg} / 100 \mathrm{~g}$ and Rambutan 33.28-58.37 mg/100g (Table 1, Fig. 6). Although there is an increase in vitamin $\mathrm{C}$ mango and Mangosteen on the 5th day, it decreased back to the 10th day.

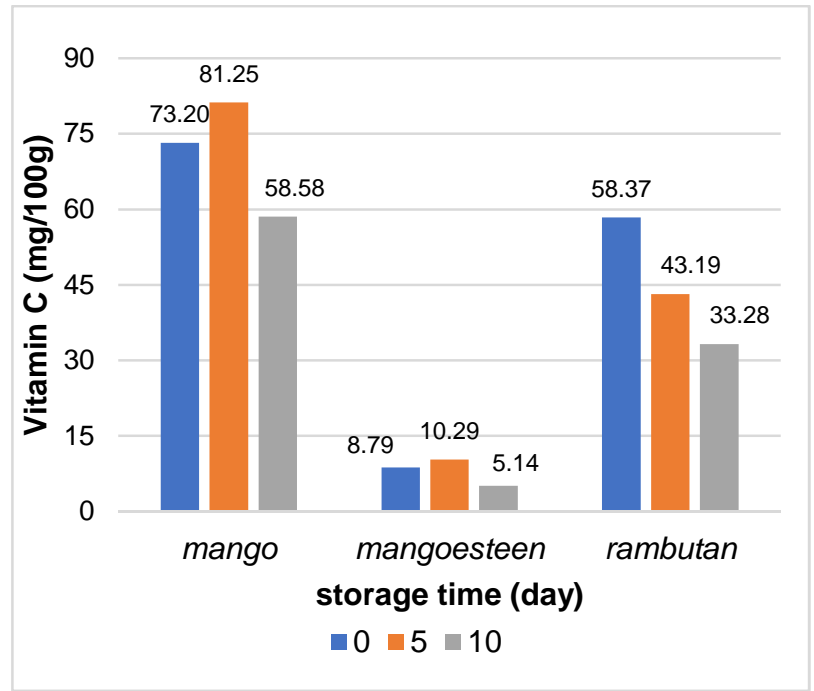

Fig. 6 Vitamin C content (mg/100g) of fresh-cut tropical fruit during storage.

Vitamin C levels decrease caused by degradation, thousands of reactions, and anthraquinone oxidation [16]. The average change is faster on Rambutan than Mango and Mangosteen. This is caused by Mango and Mangosteen fruit, including climacteric fruit that is still experiencing respiration, maturation, and production of vitamin $\mathrm{C}$ during storage [4].

\section{F. Weight shrinkage}

The weights shrinkage of Mango fruit, Mangosteen, and Rambutan increase during storage. Based on observations such as Table 1 and Fig. 7, weights shrinkage of Mangosteen increase drastically. The range of the mango weight shrinkage reduction until day 10 is $2.88 \%$, Mangosteen $9.31 \%$, and Rambutan $6.92 \%$. The longer storage kept fruit weights, and the shrinkage is high.

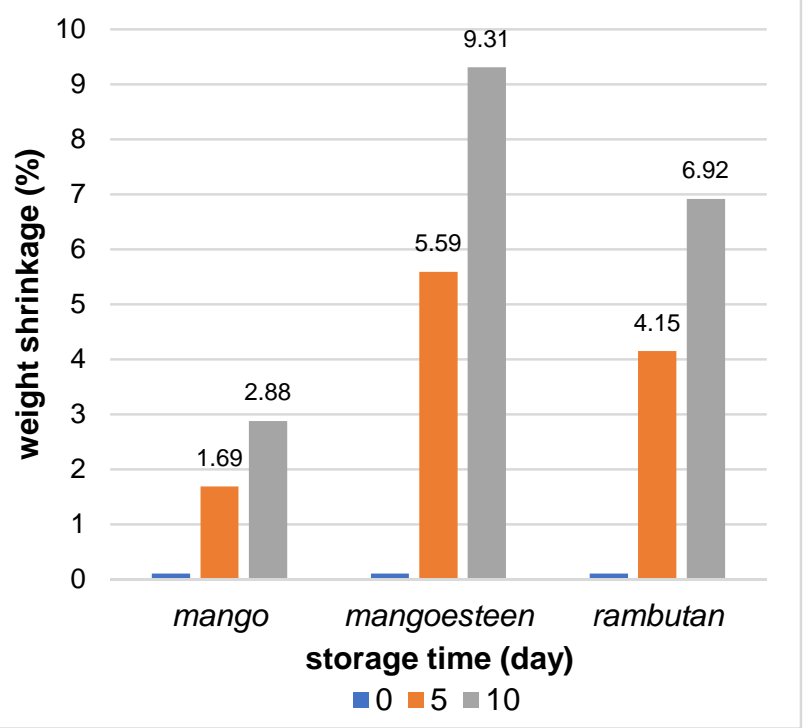

Fig. 7 Weight (g) of fresh-cut tropical fruit during storage.

Some of the effects that can be observed in fruits during storage are weight loss, respiration rate, and fruit shelf life. The minimal process causes injured fruit tissue. The tissue decay leads to increased respiration rate, leading to the rapid consumption of sugar, lipid, organic acids, and increasing the production of ethylene, which induces transpiration [9]. Protopectin decreases and transforms into acidic pectate, which is easily soluble in water. The primary wall and middle lamella cell will decrease the structure of its solids, which also leads to a decrease in fruit hardness and weight during storage [17].

\section{G. Color}

Fruit color is the main criterion used to assess the shelf life. The results show the longer the storage of fruit color value is decreasing. The Mango fruit has a range of color $\mathrm{L}^{*}$ values (39.12-51.99), a* (6.19-11.32), b* (34.71-89.51). Mangosteen $\mathrm{L}^{*}$ value is $(28.32-56.80)$, a* (-7.86-5.67), b* (13.94-19.47) and Rambutan L* (41.15 - 44.49), a* (-6.61.79), $\mathrm{b}^{*}(5.33-5.89)$ as seen in Table 1 and Fig. 8, 9, 10. Colors on all three kinds of fruits have decreased during storage. The shelf life and quality of fresh-cut fruit is considerably reduced due to a series of processes triggered by physical damage, including browning enzymatic [9].

Browning fresh-cut fruit occurs due to mechanical damage. It results in natural phenolic compounds in the vegetal tissues of the fruit oxidized by enzymes (polyphenols oxidase) in the presence of oxygen and coenzymes are (e.g., copper). The compounds are dark in color and affect the appearance of the fruit color [17]. During maturation of the 
fruit experienced some noticeable changes in color [15], [17]. The best method to retain the color of fruits is to store in a refrigerator [12].

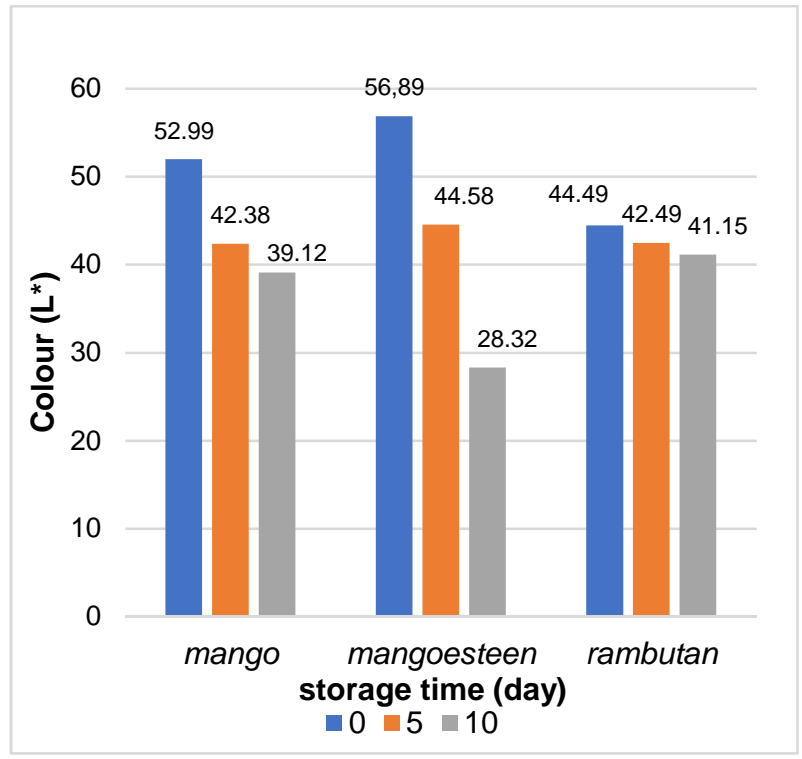

Fig. 8 Color ( $\left.\mathrm{L}^{*}\right)$ of fresh-cut tropical fruit during storage

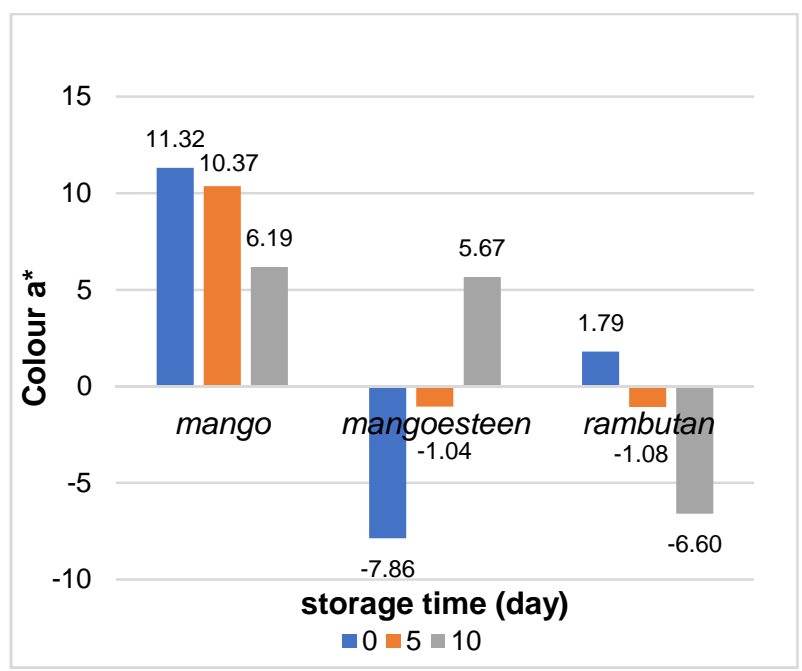

Fig. 9 Color $\left(\mathrm{a}^{*}\right)$ of fresh-cut tropical fruit during storage

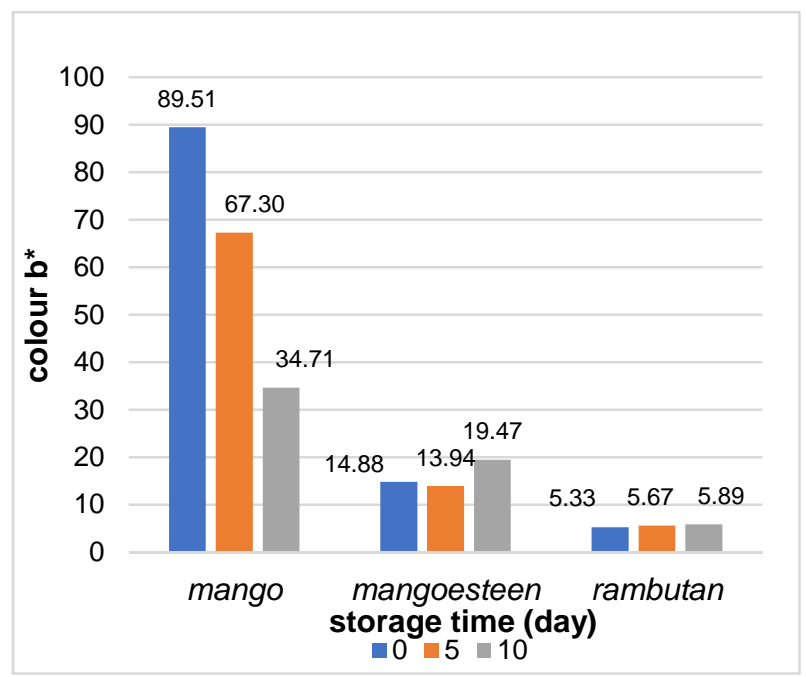

Fig. 10 Color $\left(b^{*}\right)$ of fresh-cut tropical fruit during storage.
A

B
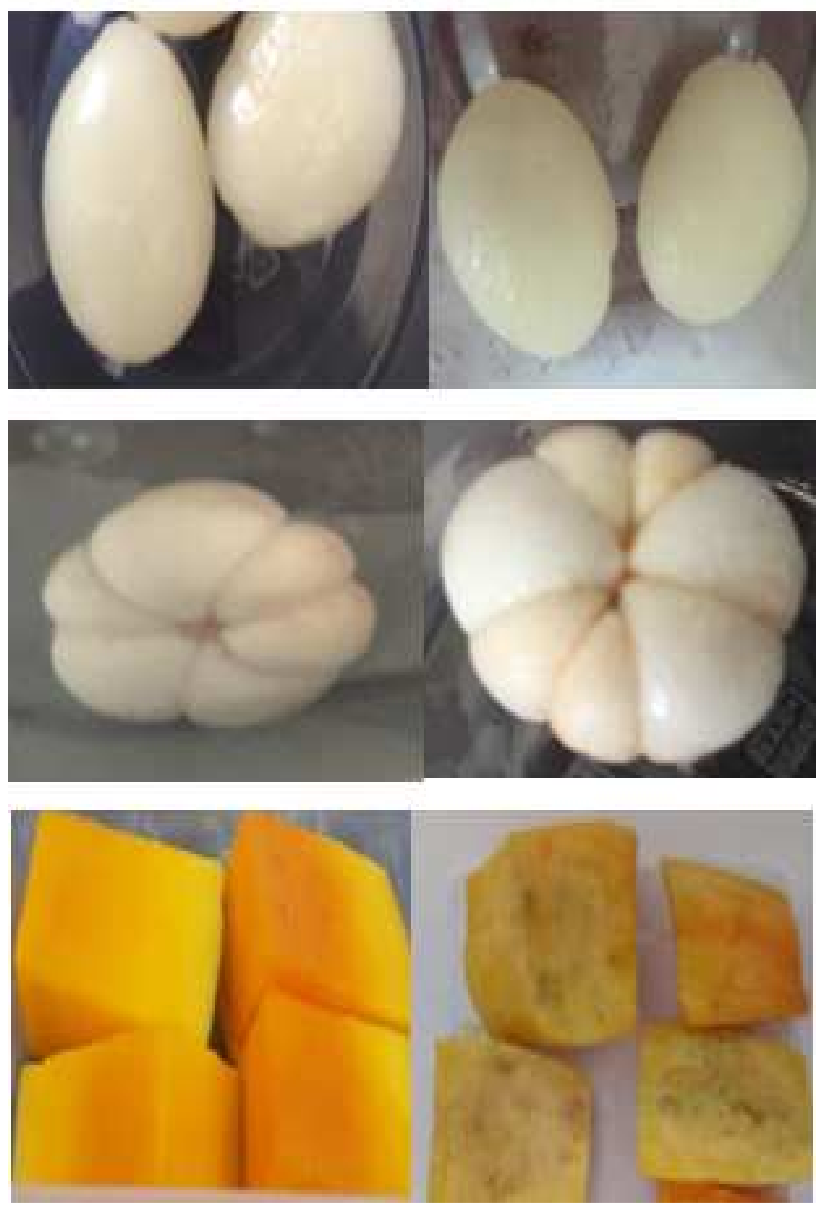

Fig. 11 Visuals of tropical fruit color day-0 (A) and day-5 (B)

\section{H. Texture}

The texture is a crucial indicator of the quality of the fruit. The texture of Mango, Mangosteen, and Rambutan during storage decreased. Table 1 and Fig. 12 Shows the value of the Mango fruit texture 1.90-3.39 N, Mangosteen 1.44-3.17 $\mathrm{N}$, and Rambutan, 2.61-7.11 N. According to [15] the process of maturation of fruit due to the process of degradation pectin to protopectin which causes the pressure Turgor cell wall decreases and causes the fruit to become soft during the maturation process. The maturation process after harvesting on green mangoes resulted in increased respiration, production of ethylene, changes in the structure of carbohydrates to be softer, chlorophyll degradation, development of pigment through the biosynthesis carotenoids [18].

The change of carbohydrate or starch conversion into sugars, organic acids, fats, phenol, and folate compounds also occurs, thereby causing the maturation of the fruit by softening the texture towards the liked quality. When the fruit is cut, peeled, or in any other way that causes injury, the tissue responds with a rise in respiration rate, consumption of sugar, lipids, organic acids, and ethylene production. This will induce maturation and cause senescence [9]. Increased maturation rates and water loss promoted by cutting and trimming mainly accelerate the decline in fruit textures. Structures such as cell walls, central lamella, and cell 
membranes undergo biochemical changes during maturation that lead to the loss of cohesion between the cells that result in a softer and weaker structure [17]. The loss of water promotes the loss of turgor cells, causing the texture of the fruit to become mushy because of the cell in the structure that shrinks [15], [18].

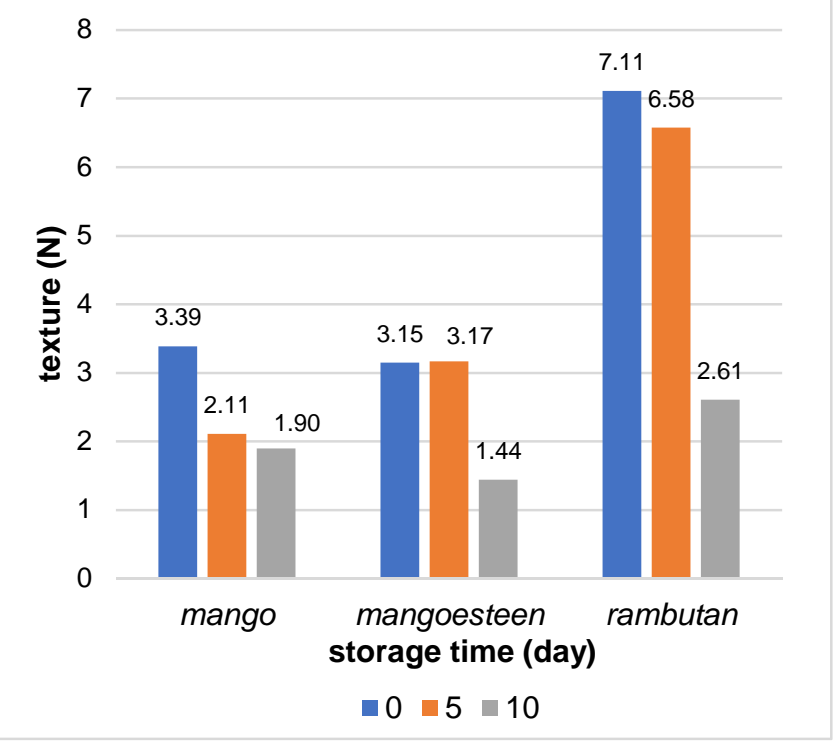

Fig. 12 Texture (N) of fresh-cut tropical fruit during storage.

\section{IV.CONCLUSION}

The results of the research stated that fresh-cut tropical fruit has different physicochemical characteristics and decreased during cold temperatures. The characteristics of Mango fruit, Mangosteen, and Rambutan have changed significantly on day 5. Mango shows more significant changes than others, seen from variable water content, vitamin $\mathrm{C}$, color, and texture.

\section{ACKNOWLEDGMENT}

We would like to thank the Ministry of Research, Technology, and the Education of the Republic of Indonesia for funding this research. We are also grateful to all colleagues who have helped this research completion.

\section{REFERENCES}

[1] J. F. Ayala-Zavala, C. Vega-Vega, C. Rosas-Domínguez, H. PalafoxCarlos, J. A. Villa-Rodriguez, M. Wasim-Siddiqui, J. E. DávilaAviña, G. A. González-Aguilar, Agro-industrial Potential of Exotic Fruit Byproducts as a Source of Food Additives, Food Research International, 44:186-1874, doi:10.1016/j.foodres. 2011.02.021, 2011.

[2] J.B. James, T.Ngarmsak, T, Processing of fresh-cut tropical fruits and vegetables: A technical Guide, Food and Agriculture Organization of the United Nations Regional Office for Asia and the Pacific Bangkok, 2010.

[3] E. Sanchísp, C. Ghidelli, C. C. Sheth, M. Mateos, L. Palou, M. B. Pérez-Gago, Integration of antimicrobial pectin-based edible coating and active modified atmosphere packaging to preserve the quality and microbial safety of fresh-cut persimmon (Diospyros kaki Thunb. cv. Rojo Brillante), Journal of the Science of Food and Agriculture, 97(1), 252-260, DOI:10.1002/jsfa.7722, 2016

[4] B. Salinas-Roca, A. Guerreiro, J. Welti-Chanes, M. D. C. Antunes, O. Martín-Belloso, Improving the quality of fresh-cut Mango using polysaccharide-based edible coatings, International Journal of Food Science \& Technology, 53(4), 938-945. DOI:10.1111/ijfs.13666, 2017.

[5] F. Artes, A. Allende, Minimal Processing of Fresh Fruit, Vegetables, and Juices. In book: Emerging Technologies for Food Processing, 677-716, DOI:10.1016/B978-012676757-5/50028-1, 2014.

[6] F. Galgano, N. Condelli, F. Favati, V. Di_Bianco, G. Perretti, M. C. Caruso, Biodegradable Packaging and Edible Coating for Fresh-cut Fruits and Vegetables, Ital. J. Food Sci., vol. 27, https://doi.org/10.14674/1120-1770/ijfs.v70, 2015

[7] M. D. Wilson, R. A. Stanley, A. Eyles, T. Ross, Innovative processes, and technologies for modified atmosphere packaging of fresh and fresh-cut fruits and vegetables, Critical Reviews in Food Science and Nutrition, 1-12. DOI:10.1080/10408398.2017.1375892, 2017.

[8] M. Alikhani, Enhancing Safety and Shelf Life of Fresh-cut Mango by Application of Edible Coatings and Microencapsulation Technique, Food Science \& Nutrition, 2(3): 210-217, DOI:10.1002/fsn3.98, 2014.

[9] S. Tappi, L. Ragni, U. Tylewicz, S. Romani, I. Ramazzina, P. Rocculi, Browning response of fresh-cut apples of different cultivars to cold gas plasma treatment, Innovative Food Science \& Emerging Technologies, DOI: 10.1016/j.ifset.2017.08.005, 2017.

[10] L. Suriati, I. G. P. Mangku, I. N. Rudianta, 2018, The Characteristics of Aloe vera Gel as Anedible Coating, IOP Conf. Ser.: Earth Environ. Sci. 207 012051, DOI:10.1088/1755-1315/207/1/012051, 2018.

[11] AOAC, Official Methods of Analytical of The Association of Official Analytical Chemist International, $21^{\text {th }}$ ed Vol 1, Editor George W. Latimmer Jr, Washington DC, 2019.

[12] G. González-González, R. M. Salinas-Hernández, A. MarcelaPiagentini, F. U. Montejo, E. Miranda-Cruz, M. Élida-Pirovani, Kinetic Parameters of Changes in Sensory Characteristics of Minimally Processed Rambutan, International Journal of Fruit Science, 16(2), 159-170. doi:10.1080/15538362.2015.1087360, 2015.

[13] B. Jarimopas, P. Pushpariksha, S. Paul-Singh, Postharvest Damage of Mangosteen, and Quality Grading Using Mechanical and Optical Properties as Indicators, International Journal of Food Properties, 12: 414-426, DOI: 10.1080/10942910701837262. 2009.

[14] M. A. Mustafa, A. Ali, G. Seymour, G. Tucker, Delayed pericarp hardening of cold stored mangosteen (Garcinia mangostana L.) upon pre-treatment with the stress hormones methyl jasmonate and salicylic acid, Scientia Horticulturae, 230, 107-116. DOI 10.1016/j.scienta. 2017.11.017, 2018.

[15] A. Abu-Bakr, Abu-Goukh, Y. M. Simaa, Elhassan, Changes in Pectic Substances and Cell Wall Degrading Enzymes During Muskmelon Fruit Ripening, K. J. Agric. Sci, 25(1),73-93, 2017.

[16] S. Hamed, H. E. Zohreh, S. Abbasi, Effect of Conventional and Ohmic Pasteurization on Some Bioactive Components of Aloe vera Gel Juice, Iran J. Chem. Chem. Eng, 34(3): 99-108, 2015.

[17] M. D. Vithana, Z. Singh, S. K. Johnson, Dynamics in the concentrations of health-promoting compounds: lupeol, mangiferin and different phenolic acids during postharvest ripening of mango fruit, Journal of the Science of Food and Agriculture, 98(4), 1460 1468. DOI:10.1002/jsfa.8614, 2017.

[18] M. Sikora, M. Świeca, Effect of ascorbic acid postharvest treatment on enzymatic browning, phenolics, and antioxidant capacity of stored mung bean sprouts, Food Chemistry, 239, 1160-1166. DOI 10.1016/j.food chem.2017.07.067. 2018

[19] L. Suriati1, I. M. S. Utama, Characteristic fillet of aloe vera gel as edible coating, J. Phys.: Conf. Ser, 1402 066021. DOI:10.1088/17426596/1402/6/066021, 2019.

[20] L. Suriati1, I. M. S. Utama, B. A. Harjosuwono, I. B. W. Gunam, Stability Aloe Vera Gel as Edible Coating. IOP Conf. Series: Earth and Environmental Science, 411.012053. DOI:10.1088/17551315/411/1/ 012053, 2020. 